\title{
TOKYO--WHAT TO DO AND HOW TO DO IT
}

For those enthusiastic people attending the FLEAT Conference who wish to go out and explore, to experience the intriguing, exciting city of Tokyo . . . this section is just for you. Do not be daunted by Tokyo's reputation as being the most expensive city in the world; there are many restaurants, places of entertainment, cultural centers and places of interest which cater ofr the average person and price themselves accordingly. Unfortunately, a visitor in Tokyo for only a few days has difficulty in discovering these establishments.

With this in mind, plus the fact that knowledge of the places you plan to visit always contributes to a more enjoyable and memorable stay, I have compiled a brief guide to Tokyo, providing practical information concerning good places to shop, eat and see, night life and other useful information.

\section{What to wear...}

Though the weather can sometimes be hot and humid in August, all the Western.style hotels and the main transportation systems are fully air-conditioned. Located in the North Temperate Zone, the climate of Japan is similar to that of the middle belt of the U.S.A. with an average temperature of $80.1^{\circ} \mathrm{F}$ and an average rainfall of 6 inches, in Tokyo, during August. Clothing worn in the U.S.A. in the summer is suitable in Japan

\section{How to get around...}

Taxis - Cruising taxis are in abundance and can be obtained on the street or at taxi zones near major hotels and office complexes. Pick up a few cards with directions written in Japenese at your hotel's front desk to give the taxi drivers, in order to get back to your hotel easier. For sight-

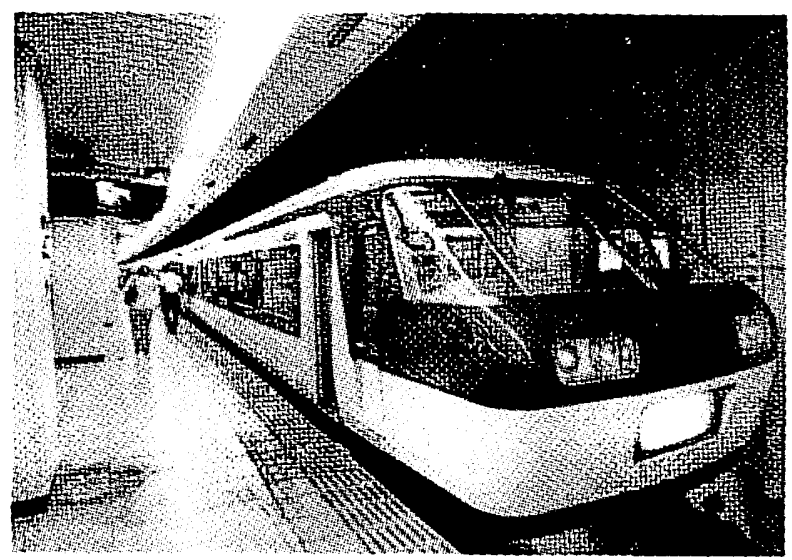

Keisel Electric Railways "Skyltiner" 
seeing and shopping you may hire sedans with an English-speaking driver by the hour through your hotel or travel agent.

Rent-a-car - As Tokyo has an extensive, efficient public transportation system it is far more convevnient to use the subway and trains both in terms of time and money.

Electric Trains - Japanese National Railways (JNR) maintains an extensive, safe and speedy network linking the city with suburbs. Signs are in both Japanese and English.

Subways - Subways offer the fastest and cheaspest way around Tokyo. Like JNR trains they are safe, punctual and economical.

Buses - Signs are only in Japanese which make buses more difficult for foreigners to use. However, bus networks are extensive and convenient for getting to points between subway and loop-line stations and other short distances.

\section{Where to eat...}

Tokyo has many excellent restaurants which serve international cuisine but if you try only Western-style foods you are missing out on a culinary treat. If you are budget-minded and want to mingle with the Japanese, look for the restaurants with show-windows that display realistic plastic replicas of the food they serve. You can tell what type of restaurant it is from the samples, the prices listed beside the samples and the outward appearance of the building. If you find the restaurant attractive, just walk in and order by pointing to the item displayed in the window.

Other inexpensive places to eat are dining roomsof department stores, restaurants in big office buildings and in underground shopping arcades, Western fast-food chains and train stations where ekiben lunch boxes can be bought very cheaply from vendors.

Some specific restaurants in the vicinity of the Imperial Hotel, in the area known as the Ginza are:

Escoffier (French) \#4-15, Ginza 5-rhome, Chuo-ku (571-4629).

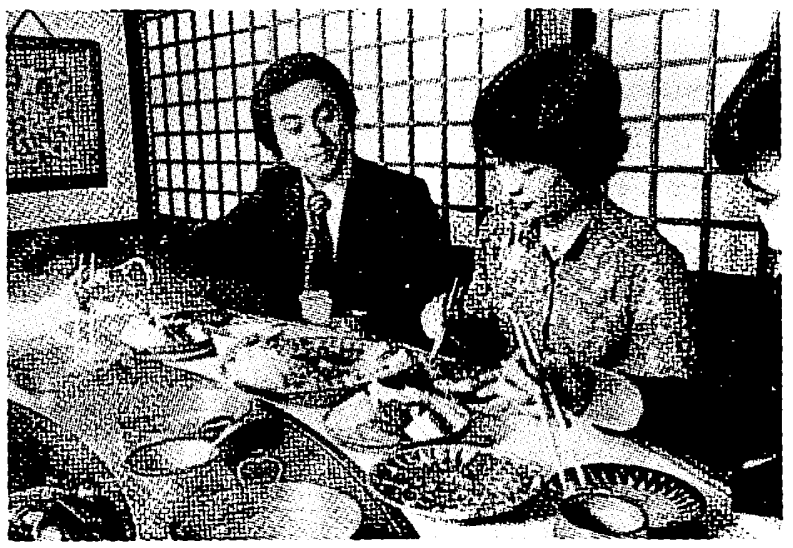

Shabu-shabu Restaurant 
Mikasakaikan (French) - \#2-15, Ginza 4-chome, Chuo-ku (566-4031).

Weiner-Wald (Beer Restaurant) - Riccar Bldg., \#2-1, Ginza 6-chome, Chuo-ku (574-6449).

Suehiro (Sukiyaki, steaks) - \#4-10, Ginza 4-chome, Chuo-ku (562-0591). Cara Calla (Italian) - \#1, Ginza-Nishi 3-chome, Chuo-ku (564-3180).

Shabu-Sen (Shabu-shabu) - Basement 2, Ginza'Core Building, \#8-20, Ginza 5-chome, Chuo-ku (572-3806).

Tori-Gin (Yakitori) - \#5-7, Ginza 5-chome, Chuo-ku (571-3333).

Ten-ichi (Tempura) - \#6-5, Ginza 6-chome, Chuo-ku (571-1949).

Tokyo Hanten (Chinese) - \#1-10, Ginza 5-chome, Chuo-ku (572-1686).

Keiraku (Chinese) \#2-8, Yurakucho 1-chome, Chiyodo-ku (580-0290).

Berni-Inn (Pub and steak bar) - 3rd. Floor, Yayoi Bldg., \#6-19, Ginza 7-chome, Chuo-ku (572-2231).

\section{Where to go after dark...}

The volume and variety of night life in Tokyo, from the simple to the splendid, is phenomenal. There are tens of thousands of establishments including bars, cabarets, nightclubs, snack bars, discotheques and beer halls. Some of them are very expensive and cater only to local businessmen with a seemingly unlimited expense account. Others cater to average office workers without expense accounts. Considering the wide range of establishments available it should not be too difficult to find a spot to suit your tastes and wallet.

Listed below are each of the main entertainment areas and a few of the recommendable places in Tokyo.

Ginza - This is Tokyo's most elegant and expensive entertainment area. At night Ginza glitters with multi-colored neon lights, becoming one of the centers of Tokyo's night life. If you're not prepared to spend a lot of money don't be put off; it is a nice place for an evening of sightseeing, window shopping and people watching.

Gin-Paris (for the music lover) - 9-11 Ginza 7-chome, Chuo-ku (571-0085). Mates (popular entertainment) - Basement 1, Ginza Corridor, Ginza 7-chome, Chuo-ku (572-8391).

Old Imperial (hotel bar) and Rainbow Lounge - Imperial, 1-1, Uchisaiwaicho 1-chome, Chiyoda-ku.

Berni Inn (pub) - 3rd. Floor, Yayoi Bldg., 6-19, Ginza 7-chome, Chuo-ku (572-2231).

Espace Giraud (pub) - Basement 3, Toho Twin Tower Bldg., 5-2, Yurakucho 1-chome, Chiyoda-ku (504-2461).

Akasaka - Akasaka is one of the most lively nighttime districts in Tokyo, with many hotels, cabarets, nightclubs and restaurants. This area is less expensive than the Ginza and most places stay open very late.

Crazy Horse (discotheque) - 18-12, Roppongi 3-chome, Minato-ku (586-3865).

Mugen (discotheque) - 8-17, Akasaka 3-chome, Minato-ku (584-4481).

Ballantine (Jazz) - 2nd., Kajimaya Bldg., 14-3, Roppongi 7-chome, Minatoku (570-0090). 


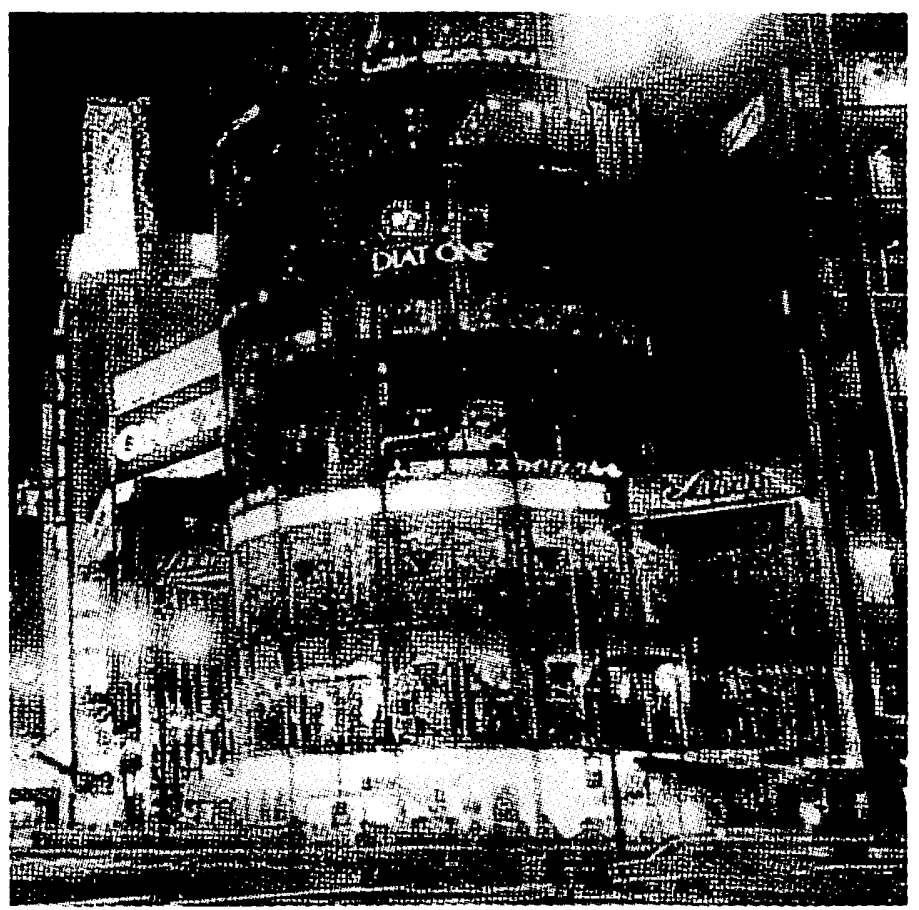

Ginza

Mingos Musico (Jazz) - 16-1, Roppongi 5-chome, Minato-ku (583-4403). Highlander (hotel bar) - Okura, 10-4, Toranomon 2-chome, Minato-ku (582-0111).

Mimi Pinson (hotel bar) - Takanawa Prince, 13-1, Takanawa 3-chome, Minato-ku (447-1111).

Mackinlay House (pub) - Basement 1, Akasaka Alto Bldg., 8-1, Akasaka 3-chome, Miniato-ku (583-8905).

The Glasshopper (pub) - 1st. Floor, Social Akasaka Bldg., 11-7, Akasaka 3-chome, Minato-ku (583-9276).

Suntory the Cellar (pub) - Suntory Bldg., 2-3, Moto-Akasaka 1-chome, Minato-ku (470-1071).

Shinjuku and Shibuya - The atmosphere in these entertainment areas is very different from Ginza and Akasaka. These areas are more boisterous and lively, and the coffee shops, cinemas, night clubs, bars and cabarets attract thousands of people from all over the city.

Canterbury, House (discotheque) - 14-20, Shinjuku 3-chome, Shinjuko-ku (354-3236).

Chester Barry (discotheque) - 4th Floor, Tatehana Bldg., Kabukicho 12, Shinjuku-ku (209-7227).

Pit Inn (Jazz) - 17-4, Shinjuku 3-chome, Shinjuku-ku (354-2024).

Taro (Jazz) - Kabukicho 21, Shinjuku-ku (209-7430). 
Adhoc (pub) - 7th. Floor, Adhoc Shinjuku Korakuen, 15-11, Shinjuku 3-chome, Shinjuku-ku (354-2108).

Eagle (pub) - Basement, Tsukahara Bldg., 24-11, Shinjuku 3-chome, Shinjuku-ku (354-7700).

Aurora (sky lounge) - Keio Plaza, 2-1, Nishi-Shinjuku 2-chome, Shinjukuku (344-0111).

\section{Where to shop...}

Tokyo is a wonderful place to shop. For convenience and variety, department stores in Nihonbashi and Ginza offer excellent shopping. They stock almost anything from antiques to the latest electronic equipment and have information desks to help tourists.

Recommended souvenirs include pearls, dolls, lacquerware, ceramics, silk brocades, woodblock prints, fans, paper lanterns and kimonos. Excellent bargains are watches, cameras and electrical appliances.

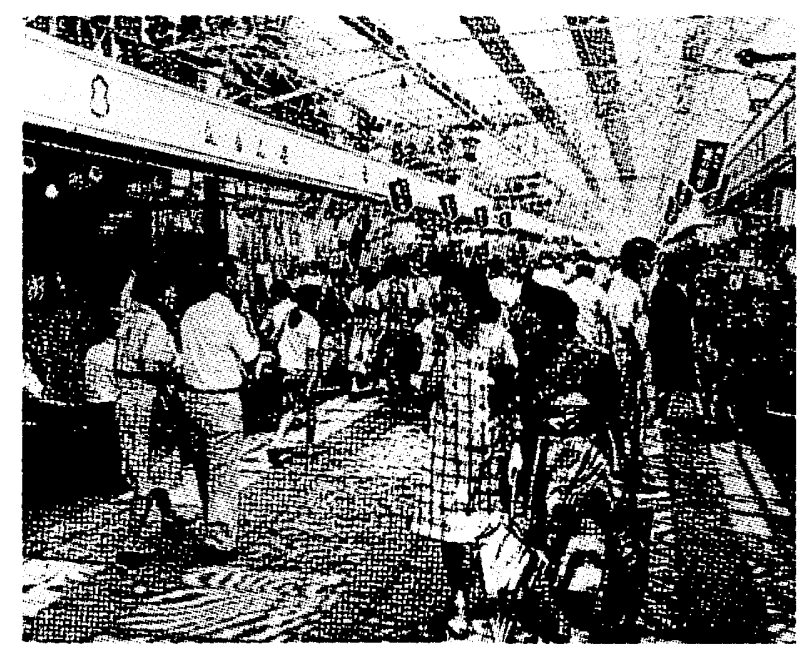

Asakusa Nakamise shopping promenade

Small neighborhood shops offer a wide range of goods at reasonable prices. Hotel arcades are convenient. Ameya Yokicho, a local market place is worth a visit. The electrical appliance discount shops at Akihabara offer a wide variety of goods but be sure to check the voltage before you buy.

\section{What to see...}

Although Tokyo is a highly westernized metropolis, it still retains much of its old-world charm. Side by side with the bustling activity of the business section, there remain traditional ways and habits of old Japan. 
The major tourist attractions in Tokyo include:

Imperial Palace - residence of the Emperor of Japan, covering 250 acres and surrounded by moats.

Kabukiza Theater - where traditional Kabuki plays are enacted.

Koishikawa Korakuen Garden - regarded as one of the best landscape gardens in Tokyo.

Marunouchi-Ohtemachi Business District - headquarters of over 1,000 large corporations and government organizations.

Meiji Shrine and Outer Garden - dedicated to Emperor Meiji and his consort, the Inner Garden covers nearly 180 acres; in the Outer Garden are the National Stadium and other sporting facilities.

National Theater - the large hall is used for Kabuki, Gagaku (traditional Japanese court music) and the smaller hall for Bunraku puppet dramas.

Rikugien Garden - covers 22 acres and features a large pond with an Sengakuji Temple - burial place of the 47 "ronin" (masterless samurai).

Suidobashi Noh Theater - traditional Noh and Kyogen plays are performer here.

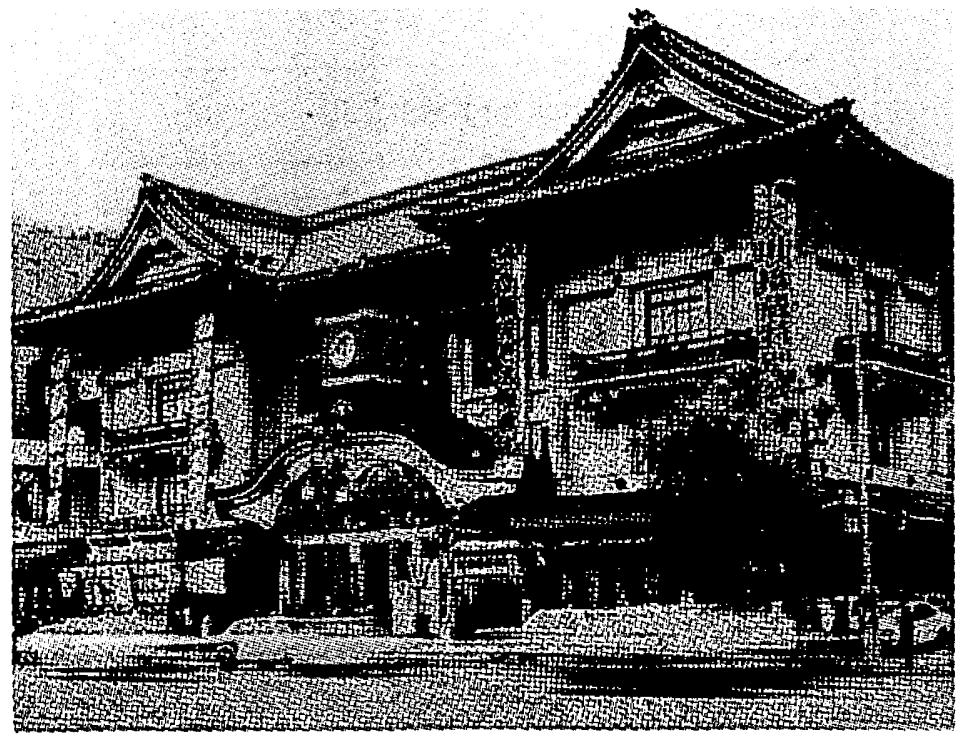

Kabukiza

Tokyo Station - handles 3,000 trains per day, including the famous "Shinkansen" or Bullet Express.

Tokyo Tower - a 1,090 feet steel tower, the highest of its kind in the world.

Toshogu Shrine - built in 1626, shows the architectural grandeur of the Edo period.

Tsukiji Fish Market - the scene of bedlam from 4 a.m. as fishermen display their catch for auction. 
Veno Zoological Garden - 900 species of animals, including pandas, are exhibited.

Yasukuni Shrine - dedicated to Japan's war dead. The 82 feet torii gate is Japan's tallest.

National Diet Building - this imposing structure houses the Japanese Parliament.

National Museum - the collection consists of artifacts from the pre-historic period in Japan, religious objects, swords and daggers, sculpture, paintings and national treasures.

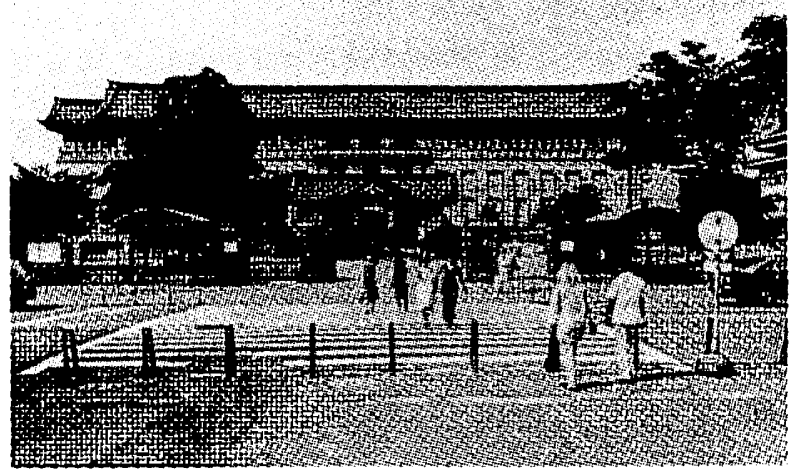

National Museum

Japan Folkcraft Museum - folkcrafts, furniture, pottery and woven items are displayed.

Art-Around-Town (full-day tour operated by the Japan Travel Bureau): Shofu Flower Arrangement School, Mrs. Ueki's Residence, Doll-making Demonstration, Woodblock Print Shop and Kimono School.

Nippon Budokan Hall (near Kudanshita Subway Station) - for those of you interested in either practising or watching the sport of Kendo, a form of fencing.

Japan Karate Association (near Ebisu JNR Station) - you can watch trainees practising the art of karate.

Aikikai (near Shinjuku JNR Station) - the martial arl of Aikido is performed here.

\section{And finally...}

Remember that information about all forms of activities and amusements is available from your hotel's information counter and the Japan National Tourist Organization 6-6, Yurakucho 1-chome, Tokyo (502-1461).

Before you say "Sayonara" make sure you "Nippon o tanoshinde kudasai - enjoy Japan."

Karen MacGregor

Graduate Assistant

Department of Special Education

University of Louisville

Louisville, Kentucky, 40292. 


\section{ABOUT THE IMPERIAL HOTEL}

In a country where persons of unique accomplishment are revered as Living National Treasures, there is a hotel - just one - that deserves such an accolade. It is the Imperial Hotel. A living legend.

The Imperial was the first western-style hotel in Japan. It was established at the request of the Imperial Household Agency to provide world-class accommodations for important government and business visitors to Japan. It is truely one of the most famous hotels in the world. FLEAT Conference attendees will be delighted at the Imperial's magnificent location between the Ginza district and the Imperial Palace. A map of the area is given below.

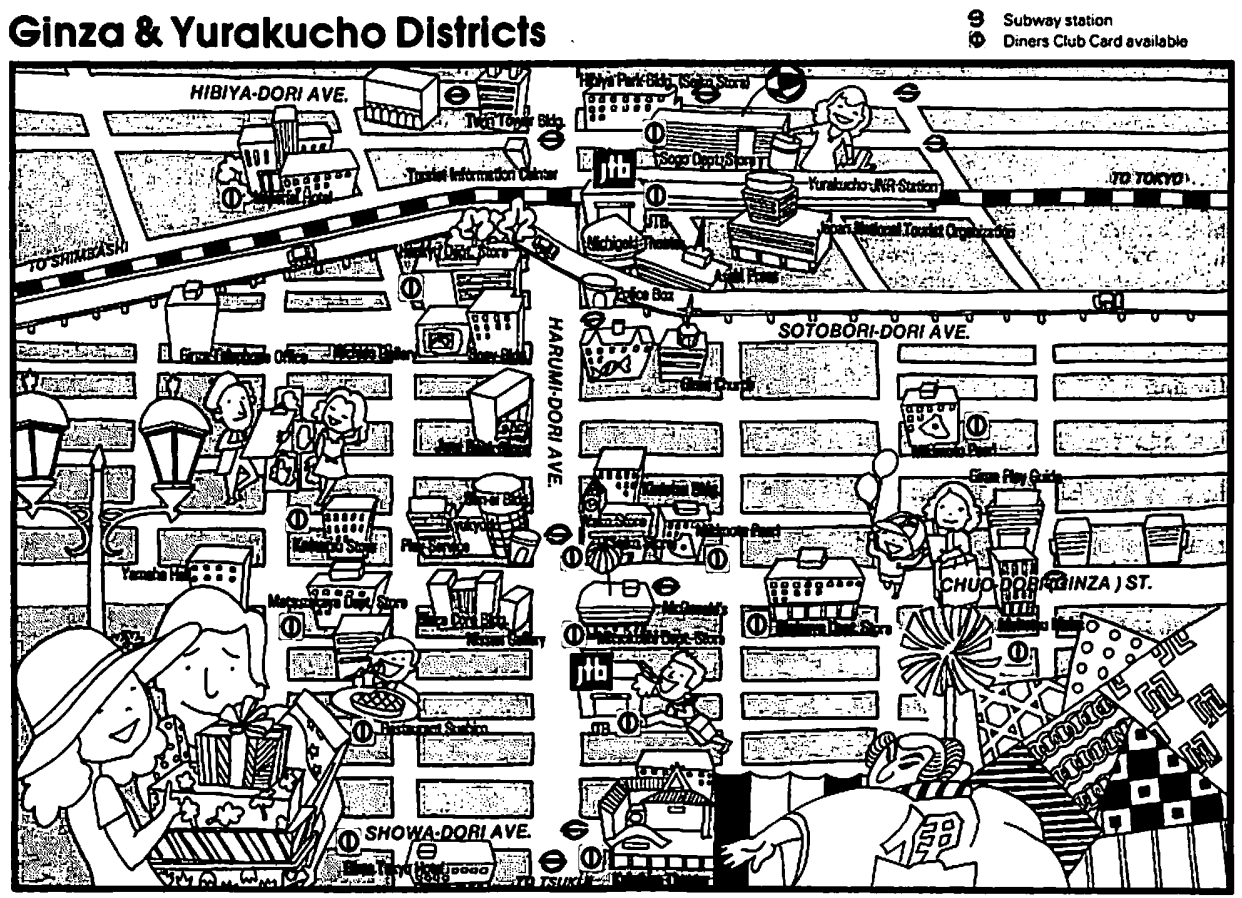




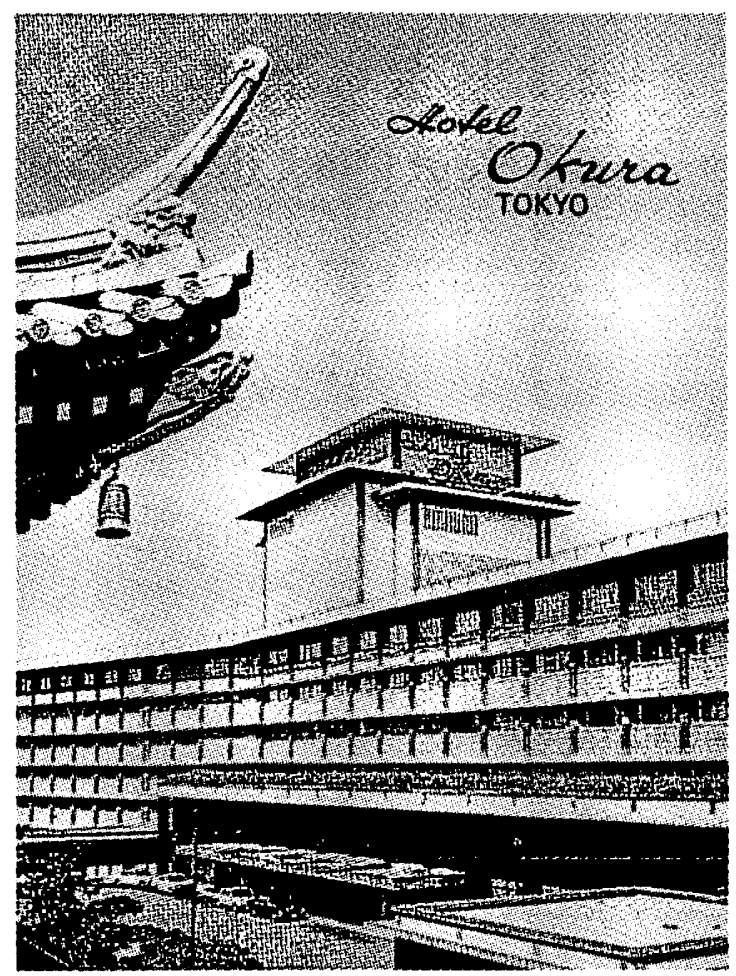

ABOUT THE OKURA HOTEL

The Headquarters for the 1981 FLEAT Conference will be in the Okura Hotel. The Okura is located in the heart of Tokyo, about one mile south of the Imperial Palace and the Imperial Hotel. The Okura Hotel brings together Japan's traditional beauty with the functional efficiency of the West. The Okura's ultramodern facilities are set in an interior that combines Japanese patterns adapted from the Kyoto Imperial Palace together the finest in contemporary Japanese and Western art. With emphasis placed on excellent accommodations, fabulous cuisine and personal service, the Okura has a well-established reputation as a luxurious "home away from home" that provides tranquility and comfort for its guests and visitors. You will like this serene hotel on a quiet hill, which is near everything in Tokyo. Transportation from the Imperial Hotel is provided via the excellent subway and bus connections The Okura is also located directly across from the American embassy. The exhibits will be located in the Gyokutei and Icho rooms located on the Banquet Room floor of the Okura's main building. (See Okura figure \# 1) The smaller meeting rooms Suehiro Matsukaze, Seiran, Seiru and Ariake are located on the second floor of the main building. (See Okura figure \# 2) Akebono is located on the Banquet Room floor of the south wing. (See Okura figure \# 3) The Momoyama and Kasuga rooms are both located on the second floor of the south wing. (See Okura figure \# 4) 


\section{本館宴会場配置図 \\ Banquet Room Floor Plan (Main Building)}

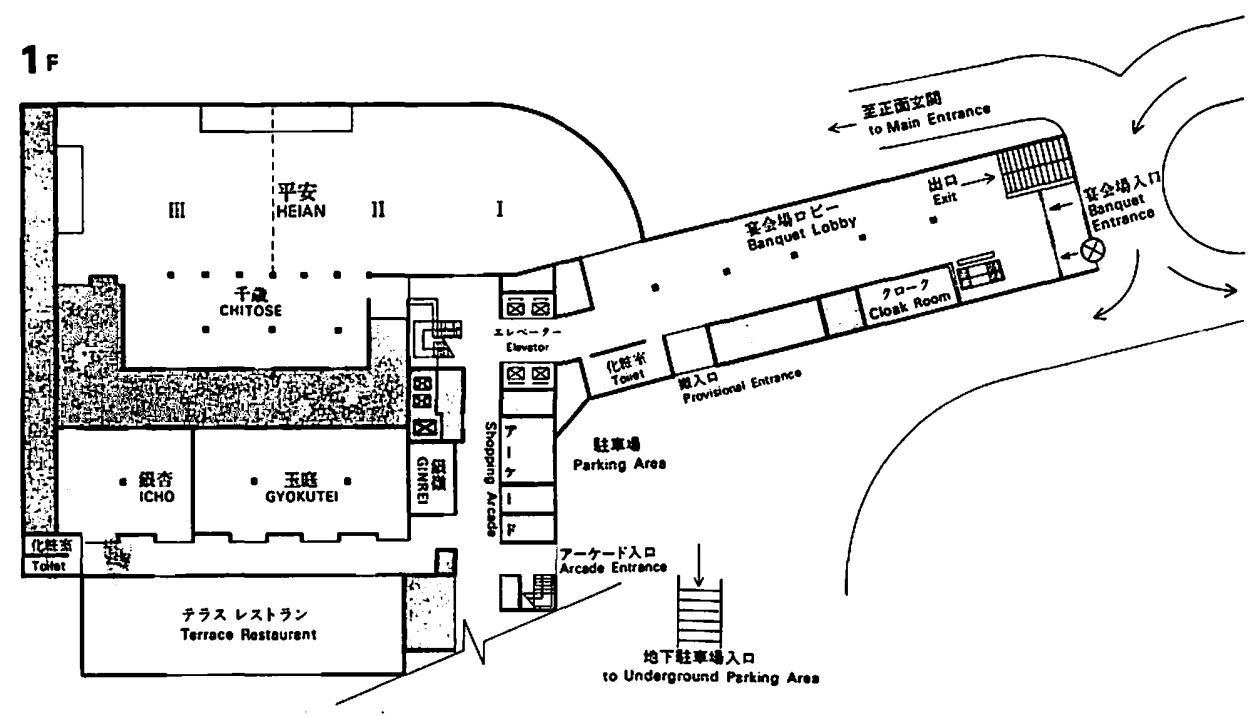

\section{OKURA Figure 1}

\section{本館(Main Building)}

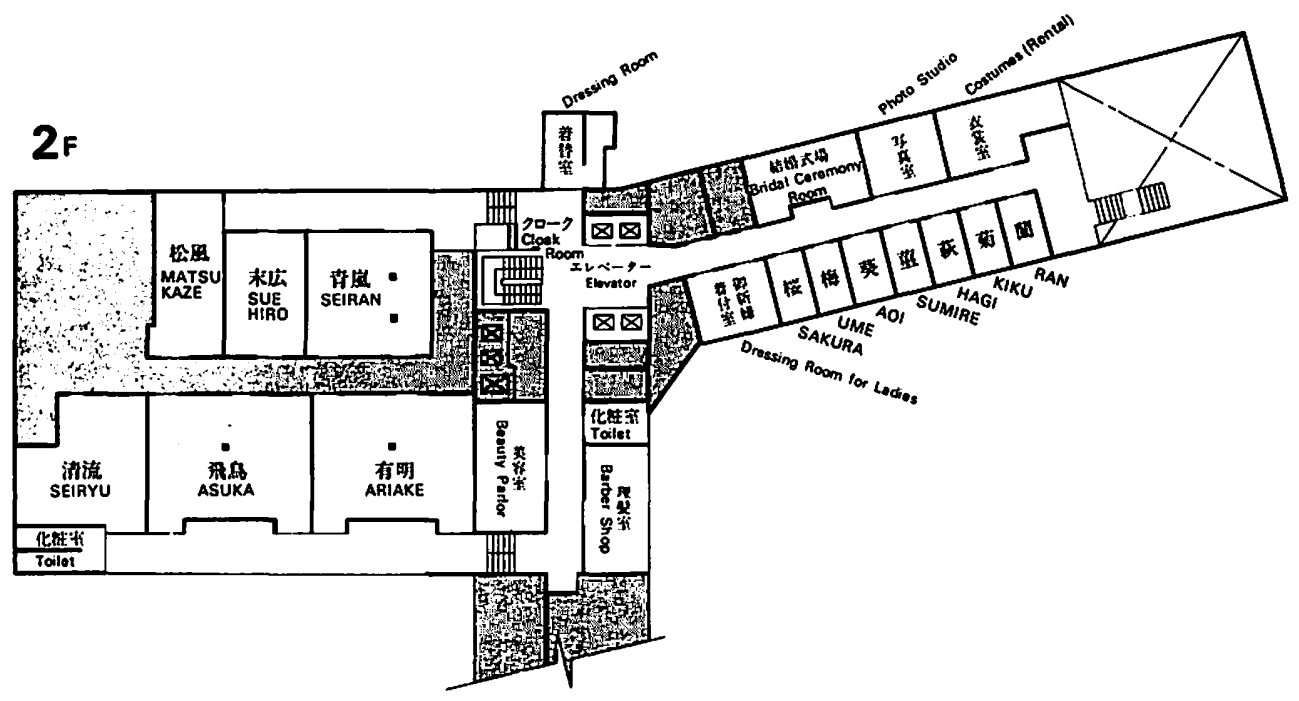

OKURA Figurt 2 


\section{別館宴会場配置図}

\section{Banquet Room Floor Plan (South Wing)}

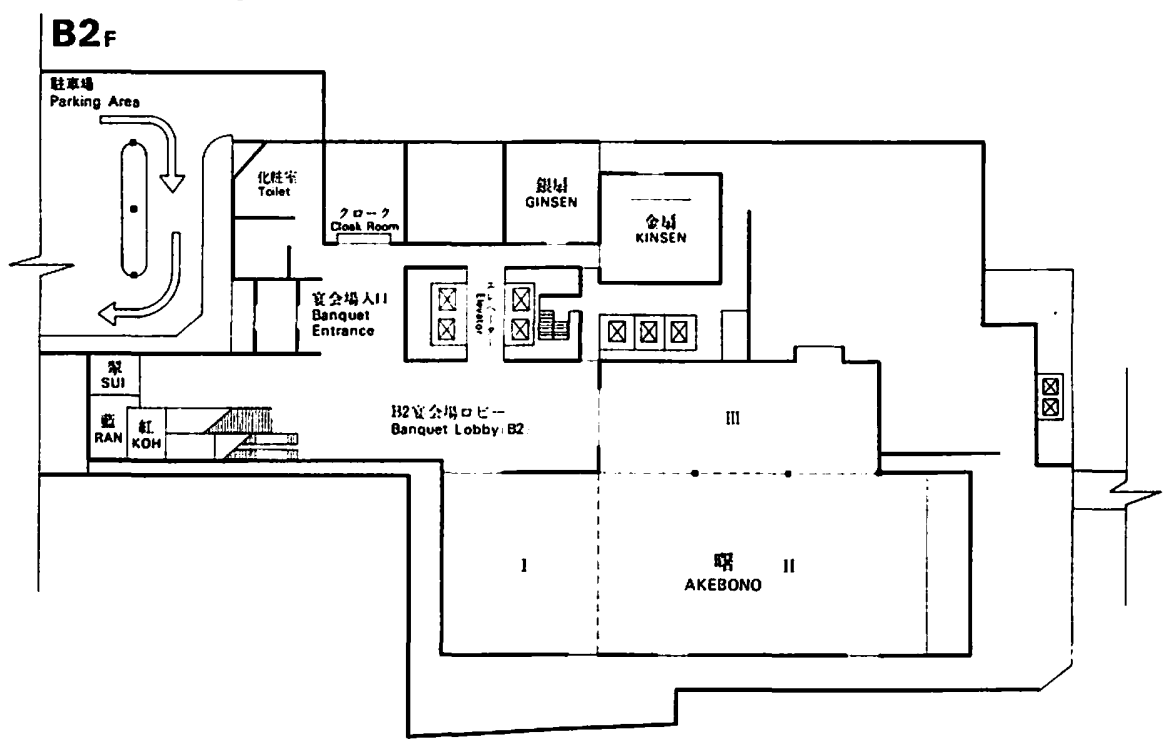

OKURA Figure 3

別館(South Wing)

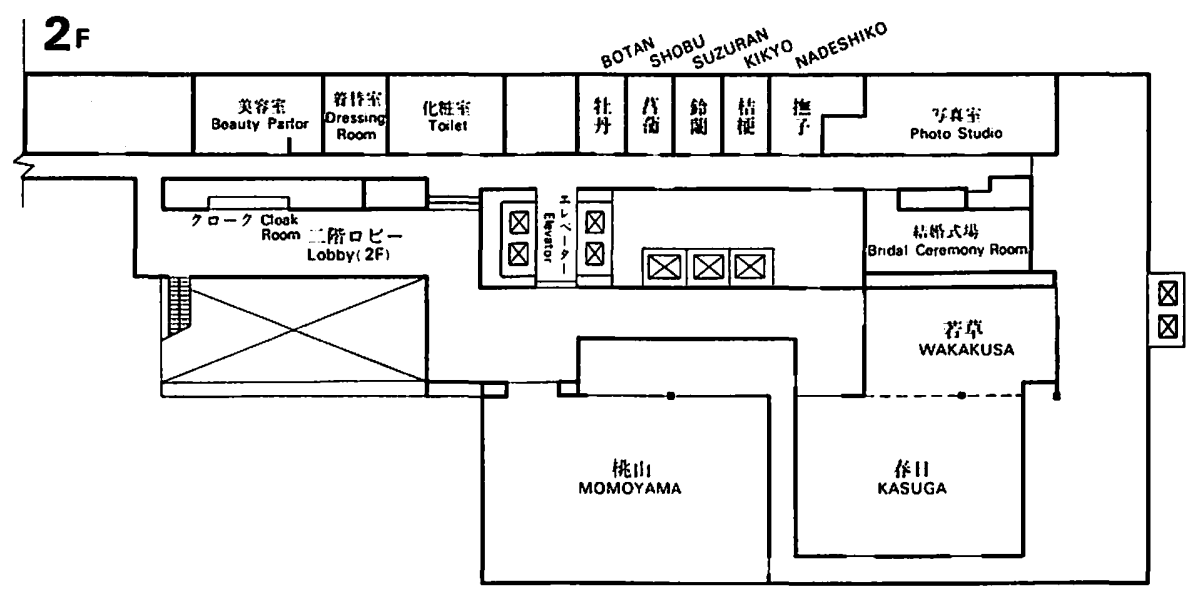

OKURA Figure 4 